\begin{tabular}{|c|l|}
\hline Title & Earthquake risk and housing prices in Japan : evidence before and after massive earthquakes \\
\hline Sub Title & \\
\hline Author & $\begin{array}{l}\text { 直井, 道生(Naoi, Michio) } \\
\text { 瀬古, 羔(Seko, Miki) } \\
\text { 隅田, 和人(Sumita, Kazuto) }\end{array}$ \\
\hline Publisher & Keio Economic Society, Keio University \\
\hline Publication year & 2009 \\
\hline Jtitle & Keio Economic Society discussion paper series Vol.09, No.2 (2009.) \\
\hline JaLC DOI & \\
\hline Abstract & $\begin{array}{l}\text { The hedonic pricing approach is used to examine whether homeowners and/or renters alter their } \\
\text { subjective assessments of earthquake risks after massive earthquakes. Using nation-wide } \\
\text { household panel data coupled with earthquake hazard information and records of observed } \\
\text { earthquakes, we find that there are some modifications of individuals' assessments of } \\
\text { earthquake risk in both cases. We have carefully taken into consideration the bias stemming } \\
\text { from the use of objective risk variables as a proxy for individual risk assessments. Our results } \\
\text { suggest that the price discount from locating within a quake-prone area is significantly larger } \\
\text { soon after earthquake events than beforehand. We argue that the most likely interpretation for } \\
\text { this result is that households tend to underestimate earthquake risk if there has not been a } \\
\text { recent occurrence. }\end{array}$ \\
\hline Notes & Technical Report \\
\hline Genre & $\begin{array}{l}\text { https://koara.lib.keio.ac.jp/xoonips/modules/xoonips/detail.php?koara_id=AA10715850-0000090 } \\
\text { 2-0001 }\end{array}$ \\
\hline URL &
\end{tabular}

慶應義塾大学学術情報リポジトリ(KOARA)に揭載されているコンテンッの著作権は、それぞれの著作者、学会または出版社/発行者に帰属し、その権利は著作権法によって 保護されています。引用にあたっては、著作権法を遵守してご利用ください。

The copyrights of content available on the KeiO Associated Repository of Academic resources (KOARA) belong to the respective authors, academic societies, or publishers/issuers, and these rights are protected by the Japanese Copyright Act. When quoting the content, please follow the Japanese copyright act. 
KESDP No. $09-2$

\title{
Earthquake Risk and Housing Prices in Japan: Evidence Before and After Massive Earthquakes ${ }^{*}$
}

\author{
Michio Naoi \\ Miki Seko ${ }^{\dagger}$ \\ and \\ Kazuto Sumita
}

\begin{abstract}
The hedonic pricing approach is used to examine whether homeowners and/or renters alter their subjective assessments of earthquake risks after massive earthquakes. Using nation-wide household panel data coupled with earthquake hazard information and records of observed earthquakes, we find that there are some modifications of individuals' assessments of earthquake risk in both cases. We have carefully taken into consideration the bias stemming from the use of objective risk variables as a proxy for individual risk assessments. Our results suggest that the price discount from locating within a quake-prone area is significantly larger soon after earthquake events than beforehand. We argue that the most likely interpretation for this result is that households tend to underestimate earthquake risk if there has not been a recent occurrence.
\end{abstract}

JEL classification: R20, C23.

Keywords: Earthquake risks, Hedonic price model, Panel data models

\footnotetext{
* To appear in Regional Science and Urban Economics. We are grateful to the National Research Institute for Earth Science and Disaster Prevention (NIED) for generously providing us with the data on earthquake hazard information. We also thank Richard Arnott, Eric Hanushek, Dwight Jaffee, Charles Leung, Colin McKenzie, Tsunao Okumura, John Quigley, Tim Riddiough, James Shilling, Jay Weiser, Jiro Yoshida, two anonymous referees and participants at the Macro, Real Estate and Public Policy Workshop, the $12^{\text {th }}$ AsRES Annual Conference and the International Conference on Economic Analysis and Policy Evaluation Using Panel Data for their helpful comments. Financial support from the Japan Economic Research Foundation is gratefully acknowledged. The first author (Michio Naoi) acknowledges a Grant-in-Aid (\#19730183) for Young Scientists from the Ministry of Education, Culture, Sports, Science and Technology. The second and third authors (Miki Seko and Kazuto Sumita) acknowledge a Grant-in-Aid (\#19530157) for Scientific Research (C) from the Ministry of Education Culture, Sports, Science and Technology. All remaining errors are ours.

${ }^{\dagger}$ Corresponding author. Faculty of Economics, Keio University, 2-15-45 Mita, Minato-ku, Tokyo 108-8345, Japan.
} 


\section{Earthquake Risk and Housing Prices in Japan: Evidence Before and After Massive Earthquakes ${ }^{*}$}

First draft: May28, 2008

First revision: June 29, 2009

Michio Naoi $^{\mathrm{a}}$, Miki Seko ${ }^{\mathrm{b} \dagger}$, Kazuto Sumita $^{\mathrm{c}}$

a. Faculty of Economics, Keio University, Mita Toho Bldg. $3^{\text {rd }}$ Floor, 3-1-7 Mita, Minato-ku, Tokyo, 108-0073, Japan

b. Faculty of Economics, Keio University, 2-15-45 Mita, Minato-ku, Tokyo, 108-8345, Japan

c. Department of Economics, Kanazawa Seiryo University, Ushi 10-1, Gosho-machi, Kanazawa-shi, Ishikawa, 920-8620, Japan

\footnotetext{
"To appear in Regional Science and Urban Economics. We are grateful to the National Research Institute for Earth Science and Disaster Prevention (NIED) for generously providing us with the data on earthquake hazard information. We also thank Richard Arnott, Eric Hanushek, Dwight Jaffee, Charles Leung, Colin McKenzie, Tsunao Okumura, John Quigley, Tim Riddiough, James Shilling, Jay Weiser, Jiro Yoshida, two anonymous referees and participants at the Macro, Real Estate and Public Policy Workshop, the $12^{\text {th }}$ AsRES Annual Conference and the International Conference on Economic Analysis and Policy Evaluation Using Panel Data for their helpful comments. Financial support from the Japan Economic Research Foundation is gratefully acknowledged. The first author (Michio Naoi) acknowledges a Grant-in-Aid (\#19730183) for Young Scientists from the Ministry of Education, Culture, Sports, Science and Technology. The second and third authors (Miki Seko and Kazuto Sumita) acknowledge a Grant-in-Aid (\#19530157) for Scientific Research (C) from the Ministry of Education Culture, Sports, Science and Technology.

$\dagger$ Corresponding Author.
} 


\begin{abstract}
The hedonic pricing approach is used to examine whether homeowners and/or renters alter their subjective assessments of earthquake risks after massive earthquakes. Using nation-wide household panel data coupled with earthquake hazard information and records of observed earthquakes, we find that there are some modifications of individuals' assessments of earthquake risk in both cases. We have carefully taken into consideration the bias stemming from the use of objective risk variables as a proxy for individual risk assessments. Our results suggest that the price discount from locating within a quake-prone area is significantly larger soon after earthquake events than beforehand. We argue that the most likely interpretation for this result is that households tend to underestimate earthquake risk if there has not been a recent occurrence.
\end{abstract}

JEL classification: R20, C23.

Keywords: Earthquake risks, Hedonic price model, Panel data models. 


\section{Introduction}

Japan is one of the world's most earthquake-prone countries since it lies at the nexus of four tectonic plates. A recent survey reports that Japan averaged 1.14 earthquake events equal to or greater than a magnitude of 5.5 on the Richter scale a year between 1980 and 2000, which according to the United Nations Development Program is fourth highest among 50 countries surveyed (UNDP, 2004). It is assumed that these massive earthquakes increase awareness of earthquake risk among individuals, largely due to extensive media coverage of the event and the resulting quake damages. Indeed, sales of earthquake insurance policies increased by $75 \%$ in Hyogo Prefecture in 1995, immediately after the Great Hanshin-Awaji (Kobe) Earthquake, and by nearly 25\% in Miyagi Prefecture after the 2003 Miyagi Earthquake, while the corresponding nation-wide increases were only $29 \%$ and $5 \%$ respectively.

If existing government anti-seismic policies are efficient in the sense that earthquake risks are properly assessed and individuals are well-informed about these risks, major tremors should not alter individuals' perception toward risk. Therefore, modifications of individuals' perceptions after an earthquake indicates that there is room for improvement in the current anti-seismic policies concerning risk assessment and its dissemination among the public.

In this paper, we use a hedonic pricing approach to estimate individuals' valuation of earthquake risk. The nation-wide household longitudinal data coupled with earthquake hazard information and the observed earthquake record allows us to investigate whether individuals, i.e., homeowners and renters, alter their subjective assessments of earthquake risks after an earthquake. Using a difference-in-differences (DID) approach with longitudinal data, we find that there are some post-quake modifications of individuals' assessments of earthquake risk. Our results indicate that, while there is no clear evidence about pre-quake responses to earthquake 
risk, both housing rents and owner-occupied home values are significantly and negatively correlated with regional earthquake risk in post-quake periods. The most plausible interpretation for these results is that both renters and homeowners are initially unaware of, or at least underestimate, earthquake risk. We also conduct several robustness checks on our main empirical findings, and compare the homeowner's implicit price estimates with capitalized insurance premiums.

The paper is organized as follows. Section 2 briefly reviews the previous studies of earthquake risk in the housing market. Section 3 presents a simple theoretical framework. Section 4 introduces the data used and explains estimation methods and variables. Section 5 presents empirical results and interpretation. Section 6 summarizes the paper and presents some conclusions.

\section{Previous Studies}

Since an earthquake is an exogenous risk factor that is tied to a specific location, its risk should be capitalized into local housing and land prices. Estimating individuals' valuation of earthquake risk is crucial for evaluating the benefits of earthquake damage mitigation policies.

There have been relatively few studies on the effect of earthquake risk on housing and land prices despite the obvious relevance to effective disaster prevention policies. Brookshire, Thayer, Tschirhart, and Schulze (1985) examine the effects of the disclosure of a risk hazard map in California on sales prices of single-family houses. It is found that the earthquake hazard indices do have a significantly negative impact on prices after they are disclosed. Nakagawa, Saito, and Yamaga (2009) empirically investigate the effect of earthquake risk on land prices using the earthquake risk index taken from the earthquake hazard map compiled by the Tokyo 
Metropolitan Government. Their results suggest that higher earthquake risk is clearly related to lower land prices in each area. Nakagawa, Saito, and Yamaga (2007) examine the impact of earthquake risk on housing rents in the Tokyo Metropolitan Area with special reference to the new Building Standard Law enacted in 1981, using the same earthquake risk index used by Nakagawa et al. (2009). They find that housing rents are substantially lower in the areas of higher earthquake risk. Also, they find that the rent of houses built prior to 1981 is discounted more substantially in risky areas than for houses built after 1981.

Beron, Murdoch, Thayer, and Vijverberg (1997) conduct hedonic analysis of residential housing prices in the San Francisco Bay area using the expected loss from earthquakes as an additional explanatory variable, and compare the estimated hedonic functions before and after the 1989 Loma Prieta Earthquake. ${ }^{1}$ The result indicates that the hazard indices have a significantly negative impact on housing prices in both time periods; however, its impact is greater in the pre-earthquake period, implying that earthquake risk was overestimated before the Loma Prieta Earthquake occurred. Significantly, they focus only on the area actually hit by the earthquake, and their results are obtained by simply comparing before and after the earthquake without any relevant control group. Thus, their results may reflect some other factors that render earthquake risk less important over time such as improvement in quake-resistant construction technology.

Compared with previous studies, our contributions are as follows. First, while previous studies mainly focus on small areas that are subject to a specific earthquake event, we use

\footnotetext{
${ }^{1}$ There are also several studies about the relationship between flood hazards and housing prices in the US. Among others, Bin and Polasky (2004) and Hallstrom and Smith (2005) investigate the effect of specific hurricane events - Floyd and Andrew - on individuals' perception of flood risks. Shilling, Benjamin and Sirmans (1987), MacDonald, Murdoch, and White (1987), MacDonald, White, Taube, and Huth (1990) and Bin, Kruse, and Landry (2008) have also evaluated the effect of flood hazard on housing values.
} 
nation-wide longitudinal data that covers areas with near-miss incidents of massive earthquakes, i.e. whose neighboring city/towns were recently hit by a massive earthquake, as well as those without any such experiences. Since housing prices are influenced by various factors varying over time, a simple before-after comparison within a small area might yield misleading conclusions. Second, we use longitudinal data rather than (repeated) cross-section data in our analysis. By observing the same households repeatedly, we can control for individual heterogeneity that influences housing price changes over time. Further, we carefully examine the bias stemming from the use of objective risk variables as a proxy for subjective assessments, utilizing the panel data instrumental variables estimator. Third, we examine whether homeowners and renters alter their subjective assessments of earthquake risks after massive earthquakes. To the best of our knowledge, there has been no prior attempt to analyze the effects of earthquake risk on property values before and after a major earthquake event for both homeowners and renters.

\section{Theoretical Considerations}

\section{Hedonic pricing model with uncertain hazardous events}

In this section, we present a simple hedonic pricing model to illustrate household responses to the prospect of hazardous events and the effect of additional information on perceptions toward risk. A similar model is also presented in MacDonald et al. (1987) and Kask and Maani (1992). The basic intuition of the model is that household's valuation of the different bundles of housing and location characteristics leads to differential housing costs. Thus, the observed discount on property in a hazardous area reflects households' risk assessment and willingness to pay to avoid such risk. In our context, given that a massive earthquake can have a potentially 
catastrophic impact on each household, and that the risk is generally fairly differentiated across regions, it is quite natural to expect that households will incorporate earthquake risk into their decision on choice of location. Rational households are willing to pay an additional amount for houses located in an area where the probability of hazard is less. Conversely, rational households may choose to locate within quake-prone areas only if they are compensated for their risk in terms of discounted housing prices that can offset the potential loss and damage from a major seismic event.

Let us assume that there are two states, 0 and 1, corresponding to a "no earthquake" and "earthquake" situation. Let $\pi$ be the probability of earthquake occurrence (i.e., the probability assigned to state 1). Hedonic pricing method suggests that housing cost can be described as a function of both housing/structural characteristics and location-specific characteristics (such as environmental factors and neighborhood quality). In our context, differentiated risk of earthquake will be a particularly important factor influencing the market cost of housing. Hence, the hedonic price function can be written as:

$$
p=p(h, \pi)
$$

where $p$ is the observed housing cost (e.g., rental price or sales price of a particular housing unit), and $h$ is a vector of housing and location-specific characteristics that are not related to earthquake risk.

A household maximizes its expected utility by choosing a bundle of housing characteristics and level of earthquake risk. ${ }^{2}$ Let $u(h, x)$ be the utility function, where $x$ is an amount of numeraire goods consumption, with $u_{h<}^{>0}$ and $u_{x}>0$. Let $y^{0}$ and $y^{1}$ be the state-contingent income where we assume $y^{0}>y^{1}$ with $L=y^{0}-y^{1}$ being the monetary

\footnotetext{
2 The preferred level of earthquake risk can be achieved by choosing a particular location of residence or by choosing levels of household expenditure on self-protection (Ehrlich and Becker, 1972).
} 
loss from the earthquake. Then the household's budget constraint suggests that the numeraire goods consumption under two states can be written as $x^{0}=y^{0}-p(h, \pi)$ and $x^{1}=y^{1}-p(h, \pi)$, respectively. The household's expected utility to be maximized can be represented as: ${ }^{3}$

$$
\max _{h, \pi} E U=\pi U\left(h, y^{1}-p(h, \pi)\right)+(1-\pi) U\left(h, y^{0}-p(h, \pi)\right) .
$$

The first-order conditions give us the equilibrium conditions required for optimal levels of the $j$ th housing/location-specific characteristics and earthquake risk.

$$
\begin{gathered}
p_{h_{j}}=\frac{\partial p}{\partial h_{j}}=\frac{\pi U_{h_{j}}^{1}+(1-\pi) U_{h_{j}}^{0}>0,}{\pi U_{x}^{1}+(1-\pi) U_{x}^{0}}<0 \\
p_{\pi}=\frac{\partial p}{\partial \pi}=\frac{U^{1}-U^{0}}{\pi U_{x}^{1}+(1-\pi) U_{x}^{0}}<0,
\end{gathered}
$$

where $U^{1}$ and $U^{0}$, respectively, represent the utility when the earthquake occurs and when it does not, and subscripts denote partial derivatives. Equation (3) indicates that the implicit price for any housing/location characteristics reflects the expected (dis-) amenity value. Equation (4) indicates that the implicit price for the probability of earthquake occurrence reflects a utility difference across states, $U^{1}-U^{0}$. Since the right-hand-side of both equations (3) and (4) are divided by the expected marginal utility of numeraire goods consumption, $\pi U_{x}^{1}+(1-\pi) U_{x}^{0}$, these implicit price estimates provide a convenient way to evaluate the marginal willingness to pay (MWP) in this simplified situation.

\footnotetext{
${ }^{3}$ Alternatively, Kask and Maani (1992) assume that households will optimally choose the level of self-protection expenditure that reduces the risk of damage from an earthquake event. The different specification of the model, however, does not change our main theoretical result.
} 


\section{The effect of earthquake insurance}

In the simplified situation above, the housing market will completely respond to the potential risk of earthquakes, and any differentiated earthquake risk will be capitalized into differentiated housing costs across regions. However, in reality, households can hedge against earthquake risk through the purchase of insurance policies. In order to examine the effect of the insurance market, we assume, in a simplified way, that earthquake insurance offers a contract with a known amount of insurance claims paid when state 1 occurs $(m)$ for the annual insurance premium $r(\pi)$ that can vary across regions depending on earthquake probability. In this case, equation (4) can be rewritten as:

$$
p_{\pi}=\frac{U^{1}-U^{0}}{\pi U_{x}^{1}+(1-\pi) U_{x}^{0}}-r_{\pi},
$$

where $r_{\pi}$ is the marginal increase in an insurance premium.

Equation (5) has at least two important implications for our benchmark result. First, in equation (5), the implicit price for the probability of earthquake occurrence $\left(p_{\pi}\right)$ is no longer equal to the household's MWP as in equation (4). This is because regional earthquake risks are partly reflected in the differentiated premiums in the insurance market. Since we expect that the true MWP (i.e., the first term on the right-hand-side) should be negative, and that the insurance premium is generally higher in risky regions (i.e., $r_{\pi}>0$ ), the implicit price for earthquake probability would overestimate the true MWP. In all, the estimates for household's MWP should be given by $p_{\pi}+r_{\pi}$. Secondly, if the claim paid by the insurer is perceived to be equal to the loss from the earthquake $(m=L)$, then income, and thus utility level, in the two states will be equal (i.e., $U^{1}=U^{0}$ ). Under these special conditions, equation (5) suggests that the implicit price estimate should be equal to the negative of the premium increment, $p_{\pi}=-r_{\pi}$. Several studies utilize this relationship to test the expected utility theory (MacDonald et al., 1987; Bin 
and Polasky, 2004; Bin et al., 2008). If, instead, the claim paid by the insurer is perceived to be less than the losses caused by the earthquake, then the household's MWP would be negative $\left(U^{1}<U^{0}\right)$, and the expected relationship would be $p_{\pi}<-r_{\pi}$. In this case, $p_{\pi}+r_{\pi}$ is the uninsured component of earthquake risk, i.e., the household's MWP under partial coverage insurance.

In Japan, as in any other countries, earthquake damage is nowhere near fully insured, and is heavily loaded reflecting the systematic nature of the risk associated with a major earthquake close to Shizuoka or Aichi prefectures. ${ }^{4}$ In addition, ex-post Japanese government grants for victims may create an immense moral hazard problem in the Japanese insurance market (charity hazard).

\section{Subjective risk assessment and the effect of information}

In the hedonic literature, concern focuses on the risk variable, $\pi$, which ideally should represent subjective risk perceptions rather than objective risk measures (Kniesner, Viscusi, Woock, and Ziliak, 2007). If consumer's subjective risk perceptions are systematically different from objective measures, empirical analysis based only on the objective measures will lead to faulty results. The maintaining assumption in almost all previous studies is that the subjective risk assessments can be proxied by objective measures of risk. ${ }^{5}$ As indicated by Maani and Kask (1991) and Kask and Maani (1992), however, the discrepancy between subjective risk

\footnotetext{
${ }^{4}$ In Japan, the premiums are based on the estimates of the likelihood of occurrence and the expected damages of an earthquake. These estimates are computed at the geographical level of prefectures, and each prefecture is classified into one of the four rating zones (rank 1 (safest) to rank 4 (riskiest)). The premiums are based on the government's regulations, not on private sector calculations.

${ }^{5}$ Although in somewhat different context, Viscusi and Aldy (2003) show that published rates of workplace injury/death are strongly correlated with workers' subjective risk perceptions.
} 
perceptions and objective risk measures will lead to biased estimates of a household's MWP in some cases. Following their approach, we specify the household's subjective probability, $\pi^{s}$, as a function of the objective probability, $\pi^{\circ}$, and the external information, I . Equation (6) gives the subjective probability function:

$$
\pi^{s}=f\left(\pi^{o}, I\right)
$$

Suppose that the market hedonic price function (equation (1)) depends on the objective probability, $p=p\left(h, \pi^{o}\right)$, but households behave according to their subjective risk perception given as equation (6). Then, for each household, the observable relationship between housing cost and subjective probability would be $p=p\left(h, g\left(\pi^{s}, I\right)\right)$, where $g(\cdot)$ is the inverse of the subjective probability function. In this case, equation (4) can be rewritten as:

$$
p_{\pi^{s}}=\frac{U^{1}-U^{0}}{\pi^{s} U_{x}^{1}+\left(1-\pi^{s}\right) U_{x}^{0}} .
$$

Equation (7) indicates that the implicit price for the subjective probability $\left(p_{\pi^{s}}\right)$ would provide the true MWP estimate. The only difference from equation (4) is that we now have the implicit price for the subjective, rather than objective, probability on the left-hand-side of the equation. Equation (7) also indicates that the implicit price for the subjective probability $\left(p_{\pi^{s}}\right)$ and the resulting MWP generally depend on the level of external information $I$, unless information does not have any influence on the household's subjective risk assessment, $f_{I}=0$. Hence we can examine modifications of households' risk perceptions by looking at the implicit price estimates under different information levels. In the following analysis, we will consider the occurrence of massive earthquakes as a major source of external information that influences households' subjective risk perceptions.

However, the above argument hinges solely on the fact that we can observe a household's subjective perceptions rather than objective measures. It can be shown that $p_{\pi^{s}}=p_{\pi^{o}} \times g_{\pi^{s}}$ 
from the relationship between housing cost and subjective probability. Therefore, due to the existence of $g_{\pi^{s}}$, the implicit price in terms of the objective probability, $p_{\pi^{o}}$, can be different from $p_{\pi^{s}}$, and would not provide the true MWP estimate as in equation (4). The multiplier $g_{\pi^{s}}$ is sometimes referred to as the transformation bias (Kask and Maani, 1992). In the following analysis, we use the appropriate instrumental variables estimator to empirically cope with this problem. If we can successfully eliminate the transformation bias from our estimates, changes in the hedonic implicit price would solely reflect changes in the household's perception of earthquake risk.

\section{Data and Methodology}

\section{Data}

The Keio Household Panel Survey (KHPS), sponsored by the Ministry of Education, Culture, Sports, Science and Technology, is the first comprehensive panel survey of households in Japan, conducted annually by Keio University since 2004. In the first wave, self-administered questionnaires were given to 4,005 respondents, male and female, aged 20-69 years. These respondents were selected by stratified two-stage random sampling.

In the following analysis, four waves of the KHPS (2004-2007) are utilized to examine the relationship between earthquake risk and housing prices in Japan. The KHPS covers both rental households and homeowners. For rental households, actual monthly rents paid are documented. For homeowners, owner-provided, self-assessed values of owner-occupied housing are documented. ${ }^{6}$ The KHPS also provides detailed information on the type of housing-ownership

\footnotetext{
${ }^{6}$ This measure of housing price is constructed from the question about subjective assessment of the value
} 
status (owned, private rental, or public rental) and construction type (wooden or reinforced concrete building). Since the anti-seismic quality of the dwelling unit largely depends on housing type, this information is necessary for evaluating the impact of seismic risk on the housing market, which is impossible in previous studies due to data limitations.

The earthquake risk measure is taken from the Probabilistic Seismic Hazard Map (PSHM) provided by the National Research Institute for Earth Science and Disaster Prevention (NIED). ${ }^{7}$ The PSHM data provides the occurrence probability of earthquakes with a given seismic intensity at a fairly disaggregated geographical level $(1 \mathrm{~km} \times 1 \mathrm{~km}$ grid cells $){ }^{8}$ In the following analysis, we use the occurrence probability of earthquakes with ground motions equal to or larger than JMA seismic intensity $6^{-}$as our risk measure. ${ }^{9}$ Since the original PSHM data provides the probability of occurrence within 30 years, we calculate the annualized version of this as $1-\left(1-\pi^{*}\right)^{1 / 30}$, where $\pi^{*}$ is the original 30-years probability from the PSHM data. An example of PSHM is shown in Figure 1.

(Figure 1 around here)

of current residence (“How much do you think this lot/house would sell for on today’s market?").

7 The original data is available at http://www.j-shis.bosai.go.jp/.

${ }^{8}$ The original PSHM data is provided as the ESRI grid format, where grid cells are defined as geographic space of equally sized square grid points. The PSHM data gives the earthquake probabilities for every $1 \mathrm{~km} \times 1 \mathrm{~km}$ grid cells all over Japan.

${ }^{9}$ The Japan Meteorological Agency (JMA) seismic intensity scale, which is measured with a seismic intensity meter, and is graded from 0 to 7 , provides a measure of the strength of seismic motion. The typical situations and damages caused by the earthquake with JMA seismic intensity $6^{-}$are as follows: People have difficulty standing, wooden houses occasionally collapse, and walls and pillars may be damaged even in highly earthquake-resistant houses. For full explanation of the JMA seismic intensity scale, see http://www.jma.go.jp/jma/kishou/know/shindo/explane.html. In general, the relationship between the JMA scale and the Richter scale basically depends on the distance from the epicenter. Even an earthquake with a small intensity on the Richter scale can have a large JMA intensity at locations near the epicenter. 
Since the unit of observation in the original PSHM is defined based on the 3rd level mesh codes $(1 \mathrm{~km} \times 1 \mathrm{~km}$ grid cells $)$, we aggregate the original data and construct the city-level probabilities in order to match the earthquake risk measure with the KHPS. ${ }^{10}$ The resulting earthquake risk variables are quite heterogeneous across prefectures; there are remarkably high earthquake probabilities in the northern and southern coastal regions of Honshu Island where some of Japan's largest cities are located (Figure 2).

\section{(Figure 2 around here)}

As mentioned above, earthquake risk variables should ideally reflect subjective perceptions rather than objective assessments. As in previous studies, we do not have information on subjective risk perceptions, but in some respects our objective estimates of earthquake probability provide a better way to disentangle price-risk tradeoffs in the housing market. First, our objective estimates are defined at the fairly disaggregated geographical level, which substantially reduces the measurement error in the earthquake risk variable. As shown in Figure 1, earthquake probabilities are highly differentiated even within the same prefecture. Therefore, our objective estimates provide a much more accurate measure of the risk associated with a particular location than a geographically broader index, such as insurance market-based hazard zones. Secondly, our risk variable varies by year as well as geographic location. ${ }^{11}$ While most previous studies use time-invariant risk measures or are based on cross-sectional analysis, time-series variation in the risk variable allows us to exploit the potential of panel data and

\footnotetext{
${ }^{10}$ This is because, in the KHPS, the information about the respondent's location of residence is reported at the city-level. In the following analysis we use the average probability within the city/town as our measure of earthquake risk. We also check several other specifications of the variable (maximum, minimum etc.), which yield virtually the same results. The city-level probabilities are calculated by ArcView 9.0.

${ }^{11}$ The PSHM is updated annually based on the status of volcanic activity or detection of new active faults. The updated earthquake occurrence probabilities are made available every January.
} 
related estimation techniques.

Our primary purpose is to investigate whether individuals alter their subjective assessments of earthquake risk after an earthquake. The occurrence of massive earthquakes is therefore thought of as a major source of external information that influences household's subjective risk perceptions.

As for this information, data is taken from the database of the Japan Meteorological Agency. ${ }^{12}$ It gives the date, epicenter, seismic intensity scale, and magnitude of noticeable tremors from 1926 onward. We create the prefecture-level dummy variable indicating that there were earthquake events with JMA seismic intensity $\geq 6^{-}$in the previous year.

We find that, although there are several massive earthquakes during our sample period, none of the cities/towns in which our sample households are located was actually hit by an earthquake with seismic intensity larger than $6^{-}$. Rather, they have witnessed the earthquakes and resulting damages in their neighboring cities and towns in the same prefecture. Therefore, the earthquakes under consideration are all in the category of a "near-miss," informing our households about the dangers without directly affecting them. As a result, we do not need to control for any repairs and reconstruction after earthquake damage that might affect housing rent and property values.

\section{Empirical Model}

Our primary interest is in estimating the hedonic implicit price of earthquake risk and its changes after massive earthquakes. The full specification of the hedonic regression model is given as follows:

$$
\ln \left(p_{i t}\right)=\alpha+\beta P R_{i t}+\gamma E Q_{i t} \times P R_{i t}+X_{i t} \delta+\mu_{i}+\phi_{t}+\varepsilon_{i t},
$$

12 The original data is available at http://www.seisvol.kishou.go.jp/eq/shindo_db/shindo_index.html/. 
where $p_{i t}$ is the appropriate housing price measure for household $i$ in time $t$ (it will be actual rent or owner-provided house value, depending on the model to be estimated), $P R_{i t}$ is the earthquake risk variable (i.e., PSHM objective probability measure), $E Q_{i t}$ is the post-quake dummy indicating that a massive earthquake (seismic intensity $\geq 6^{-}$) occurred in the previous year, $X_{i t}$ is the relevant set of explanatory variables, $\mu_{i}$ and $\phi_{t}$ are individual heterogeneity and time trends, respectively, and $\alpha, \beta, \gamma$, and $\delta$ are parameters to be estimated. Following the previous studies on hedonic analysis of the housing market, $X_{i t}$ includes basic housing characteristics such as number of rooms, floor and garden space, years since the unit was built, and the time distance to the nearest station/bus stop. We also control for construction type of the dwelling, city size, and prefecture in which the unit is located. In addition, since we use self-assessed value as owner-occupied housing price, various respondent characteristics are also included. These characteristics are: age, age squared, sex, marital status, education, employment status (private not-for-profit, private for-profit, public/government sector, self-employed, and not employed), and annual earnings. ${ }^{13}$ The definition and summary statistics of the variables are shown in Table 1.

(Table 1 around here)

Our primary interest is in the estimate of $\gamma$ in equation (8), which is the post-quake change in the effect of earthquake risk on housing prices. Since the overall effect of the earthquake risk variable on housing prices is expected to be negative, a negative estimate on $\gamma$ indicates that a massive earthquake and resulting damages in the prefecture increases residents' awareness of earthquake risks.

In equation (8), the household fixed effect $\mu_{i}$ is particularly important for two reasons. First, households living in quake-prone areas are likely to have "self-protection" for their

\footnotetext{
${ }^{13}$ Since respondent's sex and education are time-invariant characteristics, they are not included in some models with fixed effects specifications.
} 
dwellings, e.g., seismic retrofitting. Since we cannot observe the quake-resistance quality of the dwelling and such a characteristic should be included in housing prices, ignoring "self-protection" behavior could cause an underestimation of the effect of earthquake risk. In the following analysis, we assume that the quake-resistance quality of the dwelling is constant across time and can be captured by $\mu_{i}$ in our model. ${ }^{14}$ Second, the heterogeneity of attitudes toward risk might be another problem. Less risk-averse households tend to live in quake-prone areas. At the same time, it is also likely that these households will live in areas that have other unobservable risky characteristics (e.g., flood hazard). In such cases, the estimated coefficients of the model without the household fixed effect would be biased.

The possibility of another source of bias in our implicit price estimate stems from the discrepancy between subjective and objective assessments of earthquake risk. Following the recent study by Kniesner et al. (2007), we check this problem by using the familiar measurement error framework. Let $P R_{i t}^{o}$ be the objective estimate of earthquake probability and $P R_{i t}^{s}$ be the subjective risk perception. We assume that the relationship between objective probability and subjective risk perception can be represented as:

$$
P R_{i t}^{s}=P R_{i t}^{o}+v_{i t},
$$

where $v_{i t}$ represents measurement error pertaining to the household's perception toward objective risk. As shown in Section 3, the existence of the transformation bias, i.e., $g_{\pi^{s}} \neq 1$, would result in faulty MWP estimate using the objective probability measure. If there is no

\footnotetext{
${ }^{14}$ We do not distinguish between household and housing unit fixed effects here. Strictly speaking, since some households changed their residence during our sample period, these two effects are not exactly the same. In consideration of this point, we also estimated the model using a restricted sample of non-movers. However, the result does not change qualitatively.
} 
measurement error (i.e., $v_{i t}=0$ ), equation (9) immediately suggests that each household has "correct" risk assessment, and hence there is no transformation bias, $g_{\pi^{s}}=1$.

Instead, if there are certain discrepancies between objective probability and subjective risk assessment as in equation (9), the implicit price in terms of objective probability might be biased. Since our final goal is to obtain the true MWP estimate in equation (7), i.e., the implicit price for the subjective perception, the underlying model can be written as:

$$
\ln \left(p_{i t}\right)=\alpha+\beta P R_{i t}^{s}+\gamma E Q_{i t} \times P R_{i t}^{s}+X_{i t} \delta+\mu_{i}+\phi_{t}+\varepsilon_{i t}
$$

If we can observe the subjective risk measure $P R_{i t}^{s}$, equation (10) gives the implicit price for the subjective risk perception, and therefore the true MWP estimate given in equation (7). However, since we do not have any direct measure for $P R_{i t}^{s}$, equation (10) cannot be estimated in general. Instead, consider the regression of $\ln \left(p_{i t}\right)$ on the observed $P R_{i t}^{o}$. By substituting equation (9) into equation (10), we have

$$
\begin{aligned}
\ln \left(p_{i t}\right) & =\alpha+\beta\left(P R_{i t}^{o}+v_{i t}\right)+\gamma E Q_{i t} \times\left(P R_{i t}^{o}+v_{i t}\right)+X_{i t} \delta+\mu_{i}+\phi_{t}+\varepsilon_{i t} \\
& =\alpha+\beta P R_{i t}^{o}+\gamma E Q_{i t} \times P R_{i t}^{o}+X_{i t} \delta+\mu_{i}+\phi_{t}+\varepsilon_{i t}^{\prime},
\end{aligned}
$$

where $\varepsilon_{i t}^{\prime}$ is the combined error term equal to $\varepsilon_{i t}+\beta v_{i t}+\gamma E Q_{i t} \times v_{i t}$. Because $P R_{i t}^{o}$ equals $P R_{i t}^{s}-v_{i t}$, the regressor in equation (11) is correlated with the combined error term: $\operatorname{Cov}\left[P R_{i t}^{o}, \varepsilon_{i t}^{\prime}\right] \neq 0$. Hence the OLS estimates of equation (11) with observed PSHM (objective) probability become inconsistent and we need to use the instrumental variables method.

In this case, in order to obtain consistent estimates, we need to have valid instruments that are: (i) sufficiently correlated with objective probability $P R_{i t}^{o}$, while (ii) independent of the measurement error $v_{i t}$. Now suppose that the neighbor of household $i$, say household $k$, has 
a subjective assessment of $P R_{k t}^{s}$. Then, equation (9) suggests that we have $P R_{k t}^{s}=P R_{k t}^{o}+v_{k t}$ for this household. If the measurement error for each household is purely idiosyncratic, then we expect that household $k$ 's measurement error $v_{k t}$, and thus $P R_{k t}^{o}$, will be independent of household $i$ 's $v_{i t}{ }^{15}$ This allows us to use neighborhood objective probability as the instrument for $P R_{i t}^{o}$. In the following analysis, we will use within-city variation of the objective probability as our instrument, rather than picking up a single neighborhood probability associated with a particular location.

\section{Empirical Results}

In the following analyses, we estimate separate hedonic regressions for renter households and homeowners. ${ }^{16}$ Corresponding dependent variables of these two regressions are the logarithms of monthly rents and owner-provided house values. ${ }^{17}$ We first estimate the model without the interaction term $\left(E Q_{i t} \times P R_{i t}\right)$ to get our baseline result, and then estimate the full model given in equation (8).

\footnotetext{
${ }^{15}$ One may think that people in nearby locations may have similar components in their measurement errors due to unobserved location characteristics or some form of residential sorting. But if such components are time-invariant, within-difference transformation of our hedonic regression can solve this problem.

${ }^{16}$ Since our analysis is the first study to focus on both homeowners and renters' response to massive earthquakes in one paper, we cannot expect that both renters and owners react similarly based on previous research. This is the reason why we separately estimated two equations for renters and owners.

${ }^{17}$ As Kiel and Zabel (1999) and Freeman (1979) have shown, the use of the owners' valuations will result in accurate estimates of house price indexes and will provide reliable estimates of the implicit prices of housing and neighborhood characteristics.
} 


\section{Baseline Results}

Our baseline result is shown in Table 2. Here we do not distinguish between observations before and after the massive earthquakes. For both renter households and homeowners, we estimate the model with OLS and fixed effects. Models [1] and [3] are OLS results without considering household fixed effects $\mu_{i}$. Models [2] and [4] are fixed effects results. Respondent characteristics, and dummy variables for the dwelling types, prefectures and city-sizes are also controlled, but omitted from the results. We have included the time dummy variables to capture the unobserved time-varying effects that change year by year such as a housing market changes after the earthquake.

(Table 2 around here)

For renter households (Model [1]), the OLS results indicate that earthquake probability has a significantly negative effect on housing rents. This is consistent with previous studies (Naoi, Sumita, and Seko, 2007; Nakagawa et al., 2007). Based on the fixed effect estimates (Model [2]), the coefficient of earthquake occurrence probability is still negative, but not significant. Our interpretation here is that the OLS estimate may pick up unobservable household heterogeneity or some location-specific characteristics. For example, risk-averse renter households may choose better houses that are located in an area with good environmental characteristics (such as low earthquake probability, good schools or transportation links, parks or other amenities, etc.). Without controlling for fixed effects, such an unobserved relationship may yield a spurious negative correlation between housing prices and earthquake probability. Statistically, the $F$ test for the fixed effects model significantly rejects the null hypothesis of no individual effects $(\operatorname{Pr}(F(830,1223)>15.97)=0.000)$.

For homeowners (Models [3] and [4]), the negative effect of earthquake probability becomes larger and significant after controlling for individual fixed effects. It is well-known 
that the fixed effects model could exacerbate attenuation bias due to measurement errors relative to OLS if the autocorrelation in unobserved subjective perceptions is large enough relative to that in measurement errors (Wooldridge, 2002, p.311). ${ }^{18}$ Hence we expect that the measurement error problems do not play a dominant role in explaining the changes in implicit price estimates between these two models. Our intuition here is that extensive "self-protection" behavior among homeowners, which is not likely to be the case for renters, underestimates the coefficient in OLS result.

For other independent variables, the results are intuitively plausible. Age of housing and minutes from the nearest station/bus stop both have negative and significant signs except for the latter in Model [4]. Number of rooms, which is used to measure the scale of housing, has a significantly positive impact except for Model [2]. Barrier-free equipment has positive signs in homeowner results (Model [3]). As for the renter sample, this variable has the completely opposite sign without controlling for fixed effects (Model [1]), but it turns out to have a positive effect in the fixed effects model (Model [3]).

\section{Effects of Earthquake Risk Before and After Massive Earthquakes}

The main results of our hedonic regressions are shown in Table 3. Specification of the models shown in Table 3 is identical to those in Table 2 with one exception; we added an interaction term between the earthquake probability variable and a post-quake dummy variable. ${ }^{19} \mathrm{~A}$

\footnotetext{
${ }^{18}$ Strictly speaking, the argument can only be applicable to the fixed effect first-difference (FD) estimator, while our estimation method here is a standard within-difference estimator. With a longitudinal data of $T$ $>2$, estimates from these two fixed-effects estimators can be different. So we have also estimated the Model [2] with FD method, and find that this yields an even larger effect of earthquake probability.

${ }^{19}$ If there is market segmentation, the hedonic price function estimated for large areas as a whole will provide faulty estimates of the implicit prices. To see whether this is the case, we also estimate the model with a selected subset of our sample (i.e., households in northern Japan). The estimation with the
} 
post-quake dummy variable equals one if the earthquake event occurred in the previous year and zero otherwise. ${ }^{20}$

(Table 3 around here)

It is found that post-quake changes in the effect of earthquake risk probability (i.e., coefficients on an interaction term, $\gamma$ ) are significantly negative for both models. This suggests that massive quakes in neighboring cities/towns changed the perception of earthquake risk for both renter households and homeowners. Our results indicate that, in the post-quake period, a 0.2 percent increase in the annual earthquake probability, which is nearly $1 / 3$ of the average probability, leads to a 10,000 yen discount in monthly rents and a 3.8 million yen discount in housing values. These numbers are approximately $16 \%$ of average rent and $13 \%$ of housing value. Moreover, our results also indicate that the pre-quake coefficients of the earthquake risk variable are not significant in both models. Combined with the significantly negative coefficients of the interaction terms, we believe that the most plausible interpretation for this result is that households are initially unaware of, or at least underestimate, the earthquake risk in the pre-quake period. The perception of earthquake risk for both renter households and homeowners, however, changes dramatically following a massive quake in neighboring cities/towns. $^{21}$

restricted sample, however, shows qualitatively similar results.

${ }^{20}$ We also introduce a post-quake dummy variable itself as an additional explanatory variable.

${ }^{21}$ An anonymous referee kindly suggested another interpretation for the insignificant coefficient estimates of the earthquake risk variable in both the rent and house price models as follows. With any anti-seismic construction, the value of the property before the occurrence of the earthquake will increase compared to the value of the property without any anti-seismic construction. In this sense, anti-seismic construction has a direct effect on losses and thus on the value of the property. However, anti-seismic construction may also lower the risk of a loss. Because of the latter effect, as a result, the coefficient estimates of the earthquake risk variable in both the rent and house price models become insignificant. Such a story may be plausible if anti-seismic construction is prevalent in the housing market. In Japan, however, the overall percentage of dwellings with anti-seismic construction features exceeding the 


\section{Several Robustness Checks}

As we discussed in Section 3, the implicit price in terms of objective probability might be biased if there are certain discrepancies between objective and subjective risk assessments. In order to empirically check this problem, we utilize a familiar measurement error framework and re-estimate the model using the fixed effects instrumental variables estimator for objective probability (see Section 4 for detail). The instruments we used are the standard deviation of earthquake probabilities at the city/town-level (within-city S.D. of earthquake probability) and its interaction with the post-quake dummy variable. As explained before, the rationale for this choice is that, once household fixed effects are controlled for, a particular household's measurement (or perception) error is likely to be uncorrelated with its neighbor's. Hence this variable should correlate with the objective earthquake occurrence probability, but is uncorrelated with the measurement error itself.

These estimation results are summarized in Table 4 . The set of explanatory variables used in the model is identical to that of Table 3 . In this model, in contrast, the earthquake occurrence probability and its interaction with the post-quake dummy are instrumented. Various housing characteristics and other control variables are also included in the model, but are omitted from the results. ${ }^{22}$

(Table 4 around here)

regulatory minimum is less than 3\% (Housing and Land Survey, 2003).

${ }^{22}$ Housing characteristics included are as follows: age of the dwelling (years since built), time-distance from the nearest public transportation, number of rooms, floor in which the room is located (for condominium units), whether the unit has a garden (for owner-occupied houses), whether the unit has any barrier-free equipment, and dummies for the type of dwelling. The complete results are available upon request. 
The results of the first stage regressions are shown in the bottom part of Table 4. It is found that the within-city S.D. of the earthquake probability is significantly and negatively correlated with the average probability for both renter and homeowner samples. The interaction term of the within-city S.D. is also shown to be a highly significant predictor of the instrumented interactions for both models. These results indicate that our instrumental variables have sufficiently strong correlation with earthquake occurrence probability and its interaction with the post-quake dummy variable.

The second stage regression results related to earthquake occurrence probability are shown in the upper part of Table 4. Again, the post-quake changes in the effect of earthquake probability are significantly negative for both models. Moreover, even after controlling for measurement errors, estimated post-quake coefficients and the implicit price estimates are virtually identical to those presented in Table 3. To see whether measurement error problems yield significantly different parameter estimates, we test the equivalence of the results in Tables 3 and 4 by Hausman specification tests. For the renter sample, the test statistic of 1.78 , which follows $\chi^{2}(36)$ under the null hypothesis, is small enough to accept the null hypothesis. For the homeowner sample, the test statistic of 2.10 , which follows $\chi^{2}(22)$, is also small enough to accept the null. Hence we can say that our main results using objective PSHM probability as a proxy for subjective risk assessment provide sufficiently reliable implicit price estimates.

As well as the measurement error issue, the main results in Table 3 rely on the assumption that our post-quake dummy variable credibly picks up purely informational effects of the earthquake occurrence. Because a massive earthquake will have a devastating impact on the local housing market, it may affect housing prices through changes in overall demand and supply conditions. ${ }^{23}$ We have already shown in Table 3 that the post-quake dummy variable

${ }^{23}$ Kawawaki and Ota (1996) investigated the influence of the Great Hanshin-Awaji (Kobe) Earthquake 
itself does not have any significant effects in hedonic regressions, implying that the actual earthquakes under consideration do not have any direct impact on the local housing market. ${ }^{24}$ However, to examine this point in more detail, we added several neighborhood variables into our regressions. In Table 5, three neighborhood characteristics are added: Population density, per-capita income, and the number of new housing starts. ${ }^{25}$ The first two variables are expected to control for the fact that regions with dense population and/or economic activities might suffer much more extensive damage from a major earthquake. The number of new housing starts would control for the changes in demand and supply in the local housing market due to temporal shocks after a massive earthquake.

Even after controlling for these possible neighborhood effects of a massive earthquake, our pre- and post-quake implicit price estimates are still comparable with those in Tables 3 and 4 . In Model [1] for renter households, both pre- and post-quake effects of earthquake occurrence probability become significantly negative, and higher population density leads to higher rental prices as expected. In Model [2] for owner households, the post-quake effect of earthquake probability is still significantly negative with similar magnitude as those shown in the previous results. The negative coefficient on the number of new housing starts suggests that post-disaster

on the housing market in terms of changes in house prices and housing rents and analyzed the mechanism of those changes.

24 An anonymous referee kindly suggested another explanation for the positive (but insignificant) coefficient estimates of the post-quake dummy variable. If stringent anti-seismic construction codes were adopted following the earthquakes, this policy change would lead to costly housing construction, and hence have a positive impact on the price of individual housing units. Following his/her suggestion, we have checked the recent revision of the anti-seismic construction codes in Japan. We find that there are no major revisions during our sample period.

25 All three variables are defined at the prefecture-levels and calculated using the following sources. Population density: "Annual Report on Current Population Estimates" (Statistics Bureau). Per-capita income: "Annual Report on Prefectural Accounts" (Cabinet Office). Number of new housing starts: “Annual Statistics on Construction” (Ministry of Land, Infrastructure, and Transport). 
supply increases drive down local housing prices.

(Table 5 around here)

\section{Comparing Property Value Discounts with Capitalized Insurance Premiums}

We compare the predicted property value discounts with the present value of earthquake insurance premiums in Table 6 based on our results in Table 3 to investigate whether homeowners alter their subjective assessments of earthquake risks after massive earthquakes under the partial coverage insurance. As discussed in Section 3, if homeowners are well-informed about earthquake hazards and are fully insured, property value discounts along with the increased earthquake risk should be equal to the negative of the premium increment, $p_{\pi}=-r_{\pi}$. In reality, however, since earthquake insurance only covers damages and losses of housing assets and family items, earthquake risk has some components, such as injury, death, and some non-monetary losses, that cannot be insured. Hence we expect that housing price reductions might exceed the cost of earthquake insurance, that is, we expect $p_{\pi}+r_{\pi}<0$ where $p_{\pi}<0$ and $r_{\pi}>0$. The purpose of Table 6 is to examine whether $p_{\pi}+r_{\pi}$, the uninsured component of earthquake risk (i.e., the household's true MWP under the partial coverage insurance case), changes after massive earthquakes.

Since most renter households in Japan do not take out earthquake insurance, we primarily focus on homeowners and owner-provided housing values. For the calculation of earthquake insurance premiums, we assume earthquake insurance for a house with a value of 30 million yen. ${ }^{26}$ Annual insurance premiums are based on NLIRO insurance rates for wooden housing without any anti-seismic construction method. Since annual insurance premiums basically depend on the earthquake hazard of the area in which a house is located, we estimate the

\footnotetext{
${ }^{26}$ The average value of the house in our sample is about 30 million yen.
} 
premiums for four risk categories (Rank 1 (safest zone) - Rank 4 (riskiest zone)). The annual insurance payments are discounted using discount rates of 3\% (column 2) and 5\% (column3).

For the calculation of property value differentials, we use the housing value discounts from a hypothetical riskless situation (i.e., earthquake probability $=0 \%$ ). Based on the observed average earthquake probability for each risk category (column 4), predicted house values are calculated and the property value discounts are obtained. Property value discounts are defined as the predicted property value under a riskless situation minus that under an actual earthquake probability. Hence the property value discounts presented here can be interpreted as an empirical counterpart of the implicit price for the earthquake probability in absolute terms, i.e., $\left|p_{\pi}\right|$. We calculated these property value differentials for both before and after the earthquake event (columns 5 and 6).

(Table 6 around here)

When we look at the insurance premiums under a $3 \%$ discount rate, property value differentials for the pre-quake period are smaller than insurance premiums except for risk ranking 4, which means $\left|p_{\pi}\right|<r_{\pi}$ and hence $p_{\pi}+r_{\pi}>0$. Given that the Japanese insurance system does not provide full coverage, this is counterintuitive since, if $p_{\pi}+r_{\pi}>0$, equation (7) implies that the consumer has higher utility when the earthquake occurs. A possible interpretation is that pre-quake assessments of $p_{\pi}$ are underestimated, i.e., homeowners are initially in denial about earthquake risk. Assuming a 5\% discount, we can say the same thing except for risk rankings 3 and 4 . The post-quake discounts, on the other hand, generally exceed the capitalized insurance costs, i.e., $p_{\pi}+r_{\pi}<0$. These results are consistent with above interpretation that homeowners initially underestimate the earthquake risk before an actual earthquake occurs. Further, if the post-quake assessment of earthquake risk is more accurate 
than pre-quake assessments, the difference between post-quake property value discounts and the present value of insurance premiums represents the uninsurable cost of earthquakes.

\section{Conclusion}

The purpose of this paper is to examine whether individuals alter their subjective assessments of earthquake risks after massive earthquake events. We use nation-wide household longitudinal data coupled with earthquake hazard information and the observed earthquake record to estimate individuals' valuation of earthquake risk. The earthquake risk premium is estimated using hedonic price models for housing rents and owner-provided house values. Using a difference-in-differences (DID) approach with longitudinal data, we find that there are some modifications of individuals' assessments of earthquake risk following a major tectonic event. Our results for homeowners suggest that the post-quake discounts for property values within quake-prone areas more than doubled compared with pre-quake values. We argue that the most likely interpretation for this result is that homeowners initially underestimate earthquake risk.

The policy implication of our results is clear. If the government properly assesses earthquake risk and this assessment is widely disseminated among the public, occurrence of earthquake events would not substantially alter individuals' perception toward risk. In this paper, however, we find evidence of significant changes in risk assessment resulting from the actual experience of massive earthquakes. Our results indicate that there is much room for improvement in current anti-seismic disaster policies regarding public perceptions of potential earthquake losses. $^{27}$

\footnotetext{
${ }^{27}$ Quigley and Rosenthal (2008) show the importance of a diverse treatment of the economic and public aspects of urban disasters. Troy and Romm (2006) assess the effects of hazard disclosure on housing prices in statutory flood- and fire-hazard zones and analyze whether those effects were conditioned by
} 
Improved risk assessment depends on the government's extensive educational campaigns and greater transparency concerning the government's local risk assessments. In addition, the earthquake insurance system should be modified by the government to reflect more precise risk assessment. If the earthquake insurance system truly reflects more precise earthquake risk assessment, and the results are widely disseminated, households are more likely to recognize the true extent of earthquake risk in their own areas and act accordingly. ${ }^{28}$ In order to increase consumers' awareness of natural hazard risk, introduction of a law for housing lenders, sellers and real estate agents requiring disclosure of natural hazard risk, such as the 1998 California Natural Hazard Disclosure Law (AB 1195) ${ }^{29}$, might be an effective policy. It is important to remind households to always properly assess earthquake risk even if they have never experienced massive earthquakes in their areas, and these reminders are most likely to be effective at the point of sale, i.e. real estate brokers and housing lenders. Our results suggest that, prior to massive earthquakes, homeowners tend to underestimate earthquake risk, or are totally unaware that they live in a quake-prone area, and thus do not adopt adequate anti-seismic measures or purchase insurance policies. This lack of awareness justifies some form of government intervention regarding anti-seismic policies that help people better assess and address their risk.

The government should devise anti-seismic policies reflecting accurate earthquake risk assessment in each area. For example, the government should impose strict anti-seismic building codes for buildings in risky areas and encourage households to modify their dwellings to lessen seismic risk. Targeted subsidies and tax deductions aimed at promoting seismic risk

race/ethnicity, income, and previous occurrence of hazards in those zones.

${ }^{28}$ Kunreuther (2008) examined the role that insurance and mitigation can play in reducing losses from natural disasters.

${ }^{29}$ For the details of the AB1195, see Troy and Romm (2006). 
counter-measures could nudge households to upgrade their dwellings. The government could also impose risk premiums on businesses and target tax deductions and subsidies to encourage companies to locate offices and factories in less earthquake prone areas as a way of shifting population away from riskier areas. The haunting images from Sichuan are compelling reasons for adopting more proactive policies in Japan.

\section{References}

Beron, K.J., J.C. Murdoch, M.A. Thayer, and W.P.M. Vijverberg (1997), "An Analysis of the Housing Market before and after the 1989 Loma Prieta Earthquake," Land Economics, 73(1), pp.101-113.

Bin, O., and S. Polasky (2004), "Effects of Flood Hazards on Property Values: Evidence Before and After Hurricane Floyd," Land Economics, 80(4), pp.490-500.

Bin, O., J.B. Kruse and C.E. Landry (2008), "Flood Hazards, Insurance Rates, and Amenities: Evidence from the Coastal Housing Market.” Journal of Risk and Insurance, 75(1), pp.63-82.

Brookshire, D.S., M.A. Thayer, J. Tschirhart, and W.D. Schulze (1985), “A Test of the Expected Utility Model: Evidence from Earthquake Risks," Journal of Political Economy, 93(2), pp.369-389.

Ehrlich, I. and G.S. Becker (1972), "Market Insurance, Self-Insurance, and Self-Protection," Journal of Political Economy, 80, pp.623-648.

Freeman M. (1979), "Hedonic Prices, Property Values and Measuring Environmental Benefits: A Survey of the Issues." Scandinavian Journal of Economics, 81(2), pp.155-173.

Hallstrom, D.G., and V.K. Smith (2005), "Market Responses to Hurricanes," Journal of 
Environmental Economics and Management, 50(3), pp.541-561.

Kask, S.B. and S.A. Maani (1992),“Uncertainty, Information, and Hedonic Pricing,” Land Economics, 68(2), pp.170-184.

Kawawaki, Y. and M. Ota (1996), "The Influence of the Great Hanshin-Awaji Earthquake on the Local Housing Market,” Review of Urban and Development Studies, 8, pp. 220-233.

Kiel, K.A and J.E Zabel (1999), "The Accuracy of Owner-Provided House Values: The 1978-1991 American Housing Survey,” Real Estate Economics, 27(2), pp.263-298.

Kniesner, T.J., W.K. Viscusi, C. Woock and J.P. Ziliak (2007), "Pinning Down the Value of Statistical Life," IZA DP No. 3107. Available at http://ssrn.com/abstract=1029912/.

Kunreuther, H. (2008), "Catastrophe Insurance: Challenges for the U.S. and Asia," Paper presented at the 2008 ASSA Annual meetings in New Orleans.

Maani, S.A. and S.B. Kask (1991), "Risk and Information: a Hedonic Price Study in the New Zealand Housing Market,” Economic Record, 67(3), pp.227-236.

MacDonald, D.N., J.C. Murdoch and H.L. White (1987), "Uncertain Hazards, Insurance, and Consumer Choice: Evidence from Housing Market," Land Economics, 63(4), pp.361-371.

MacDonald, D.N., H.L. White, P.M. Taube, and W.L. Huth (1990), "Flood Hazard Pricing and Insurance Premium Differentials: Evidence from the Housing Market," Journal of Risk and Insurance, 57(4), pp.654-663.

Nakagawa, M., M. Saito, and H. Yamaga (2009), "Earthquake Risks and Land Prices: Evidence from the Tokyo Metropolitan Area," Japanese Economic Review, 60(2), pp.208-222.

Nakagawa, M., M. Saito, and H. Yamaga (2007), "Earthquake Risk and Housing Rents: Evidence from the Tokyo Metropolitan Area," Regional Science and Urban Economics, 37(1), pp.87-99.

Naoi, M., K. Sumita, and M. Seko (2007), "Earthquakes and the Quality of Life in Japan," 
Journal of Property Research, 24(4), pp.313-334.

Quigley, J.M. and L. Rosenthal (2008), Risking House and Home: Disasters, Cities, Public Policy, Berkeley, CA: Berkeley Public Policy Press.

Shilling, J.D., J.D. Benjamin, and C.F. Sirmans (1985), “Adjusting Comparable Sales for Floodplain Location,” Appraisal Journal, 53(3), pp.429-436.

Troy, A. and J. Romm (2006), "An Assessment of the 1998 California Natural Hazard Disclosure Law (AB 1195),” Policy Research Program, California Policy Research Center, University of California.

United Nations Development Programme (2004), Reducing Disaster Risk: A Challenge for Development, New York: John S. Swift Co.

Viscusi, W.K. and J. Aldy (2003), "The Value of a Statistical Life: A Critical Review of Market Estimates throughout the World," Journal of Risk and Uncertainty, 27(1), pp.5-76.

Wooldridge, J.M. (2002), Econometric Analysis of Cross-Section and Panel Data, Cambridge, MA: MIT Press. 
Figure 1: Example of the Prababilistic Seismic Hazard Map (PSHM)

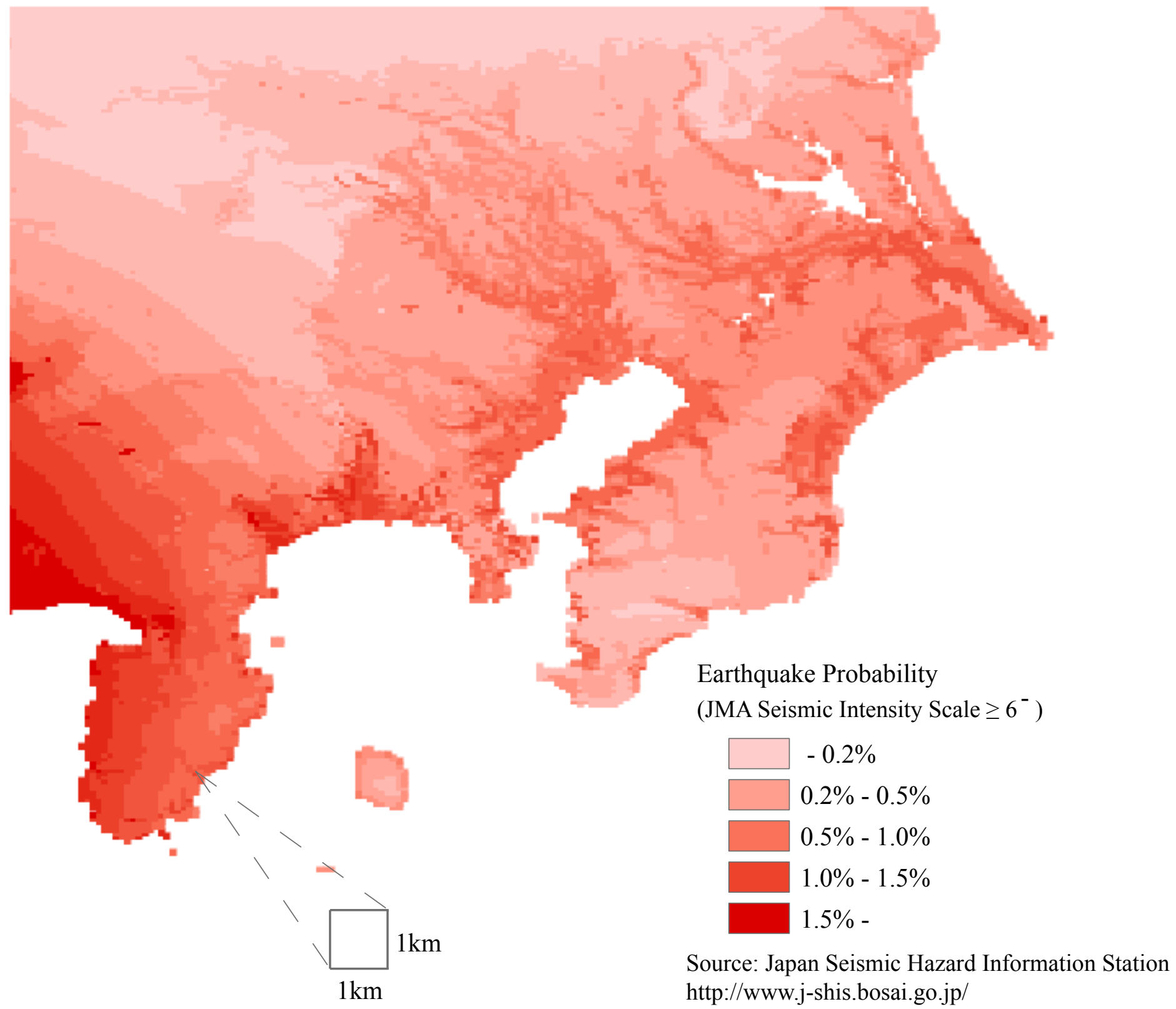


Figure 2: Earthquake Occurrence Probability by Prefecture

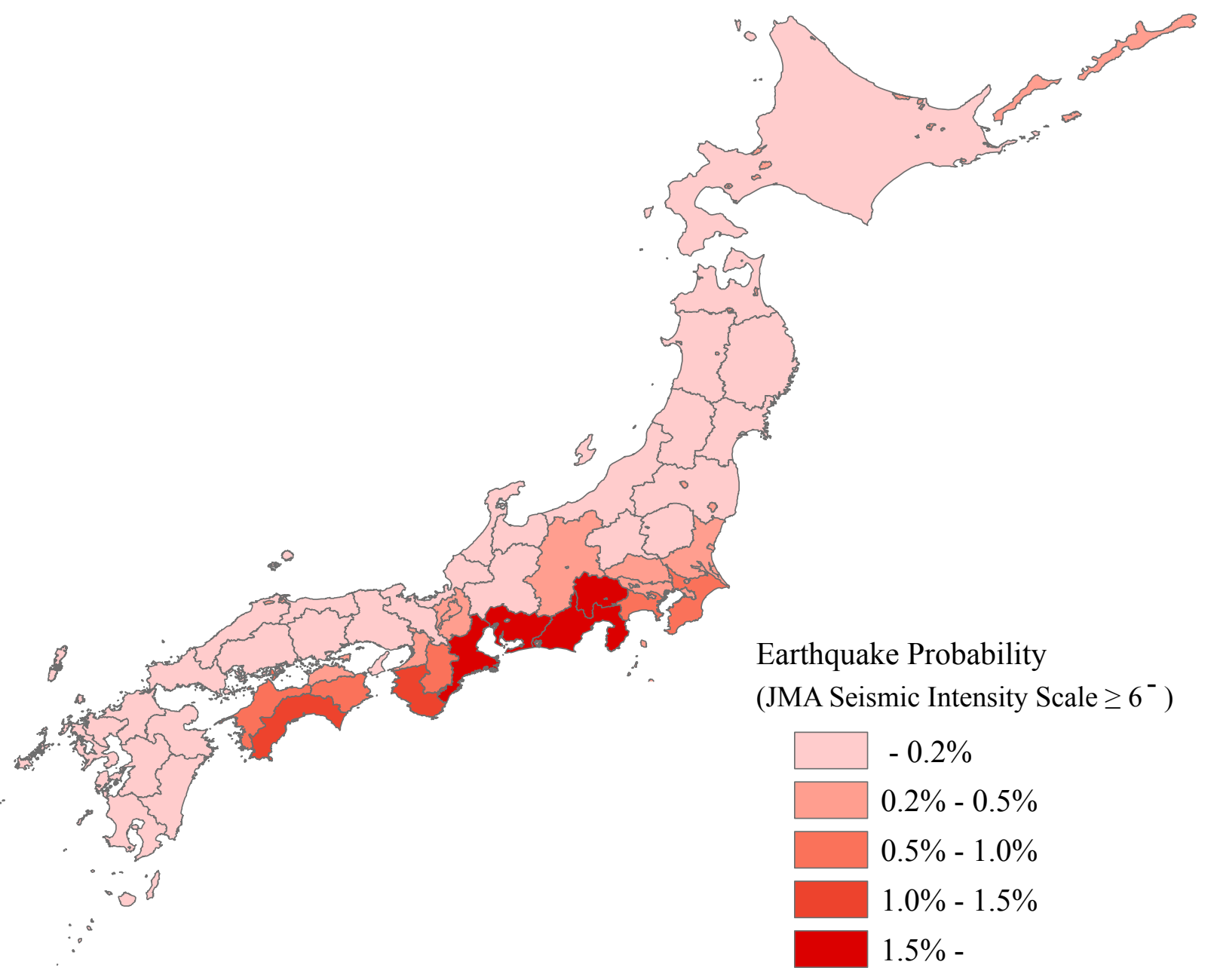

Source: Japan Seismic Hazard Information Station http://www.j-shis.bosai.go.jp/ 
Table 1: Variable Definitions and Summary Statistics

\begin{tabular}{|c|c|c|c|c|}
\hline \multirow[t]{2}{*}{ 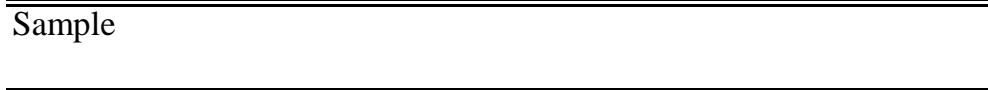 } & \multicolumn{2}{|c|}{ 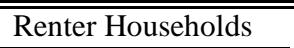 } & \multicolumn{2}{|c|}{ Homeowners } \\
\hline & Mean & (S.D.) & Mean & (S.D.) \\
\hline \multicolumn{5}{|l|}{ Housing Prices } \\
\hline Housing rent (10,000 yen / month) & 6.172 & (3.267) & & \\
\hline Owner-provided value (10,000 yen) & & & 2966.5 & $(2648.2)$ \\
\hline \multicolumn{5}{|l|}{ Earthquake Variables } \\
\hline Earthquake occurrence probability (\%, annual, JMA intensity $\geq 6$ ) & 0.589 & $(0.798)$ & 0.640 & $(1.004)$ \\
\hline $\begin{array}{l}\text { Post-quake dummy (= } 1 \text { if the earthquake with JMA intensity } \geq 6^{-} \\
\text {occurred in the previous year) }\end{array}$ & 0.048 & $(0.214)$ & 0.039 & $(0.194)$ \\
\hline \multicolumn{5}{|l|}{ Housing Characteristics } \\
\hline Age of the building (years since built) & 19.171 & (12.869) & 20.713 & (14.223) \\
\hline Time-distance from the nearest railway station/bus stop (in min.) & 8.610 & $(6.893)$ & 10.151 & (9.273) \\
\hline Number of rooms & 3.381 & (1.197) & 6.183 & (1.880) \\
\hline Floor in which the room is located & 1.891 & (1.973) & & \\
\hline House with a garden & & & 0.771 & $(0.420)$ \\
\hline Any barrier-free equipments for elderly & 0.268 & $(0.443)$ & 0.521 & $(0.500)$ \\
\hline \multicolumn{5}{|l|}{ Type of dwelling } \\
\hline One-unit building detached from any other buildings & 0.182 & $(0.386)$ & 0.984 & $(0.126)$ \\
\hline One-unit building attached to one or more buildings & 0.047 & $(0.211)$ & 0.013 & $(0.114)$ \\
\hline Reinforced concrete building with two or more apartments & 0.558 & $(0.497)$ & 0.002 & $(0.039)$ \\
\hline Wooden building with two or more apartments & 0.197 & $(0.398)$ & 0.001 & $(0.024)$ \\
\hline Other type of building & 0.016 & $(0.125)$ & 0.001 & $(0.028)$ \\
\hline \multicolumn{5}{|l|}{ Location Characteristics } \\
\hline 14 major cities & 0.347 & $(0.476)$ & 0.193 & $(0.395)$ \\
\hline Other cities & 0.571 & $(0.495)$ & 0.619 & $(0.486)$ \\
\hline Towns/villages & 0.081 & $(0.273)$ & 0.187 & $(0.390)$ \\
\hline $\mathrm{N}$ & 2,2 & & 5 , & \\
\hline
\end{tabular}


Table 2: Effects of Earthquake Risk Measures on Housing Prices

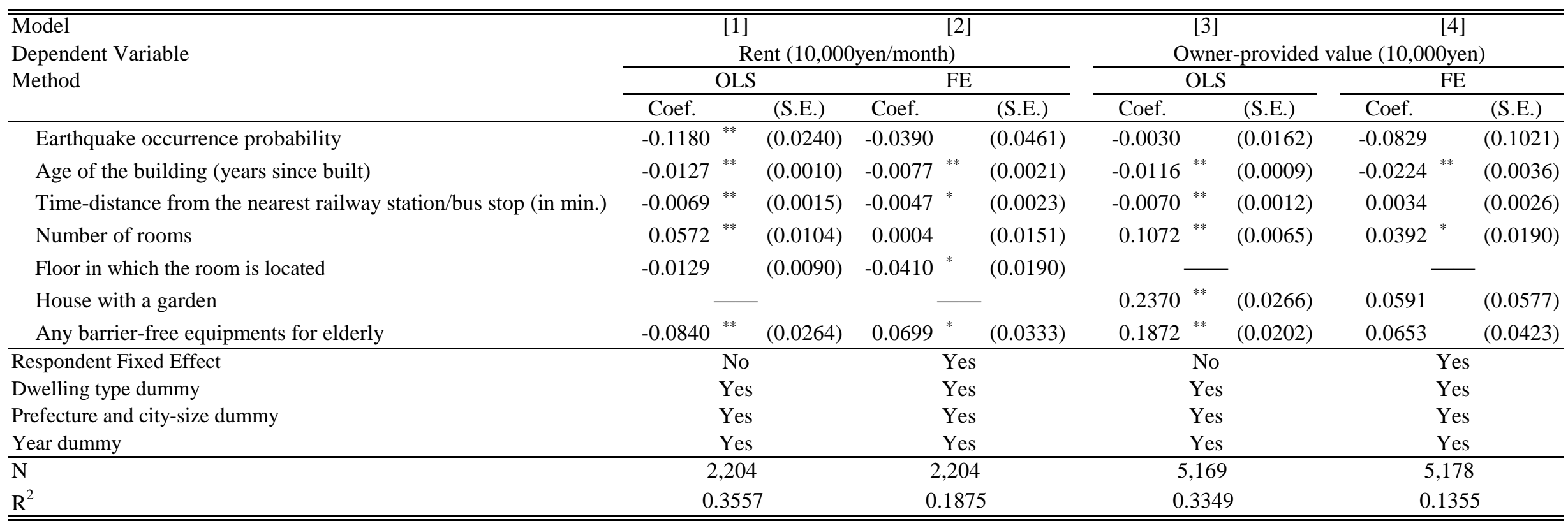

Notes :

${ }^{* *},{ }^{*}$, and ${ }^{+}$indicate that the estimated coefficient is significant at the $0.01,0.05$ and 0.10 levels, respectively. Dummy variables for dwelling types, prefectures, city-sizes, and survey years are also controlled but are omitted from the results. Robust standard errors are reported in the parentheses. 
Table 3: Effects of Earthquake Risk Measures Before and After Earthquake Events

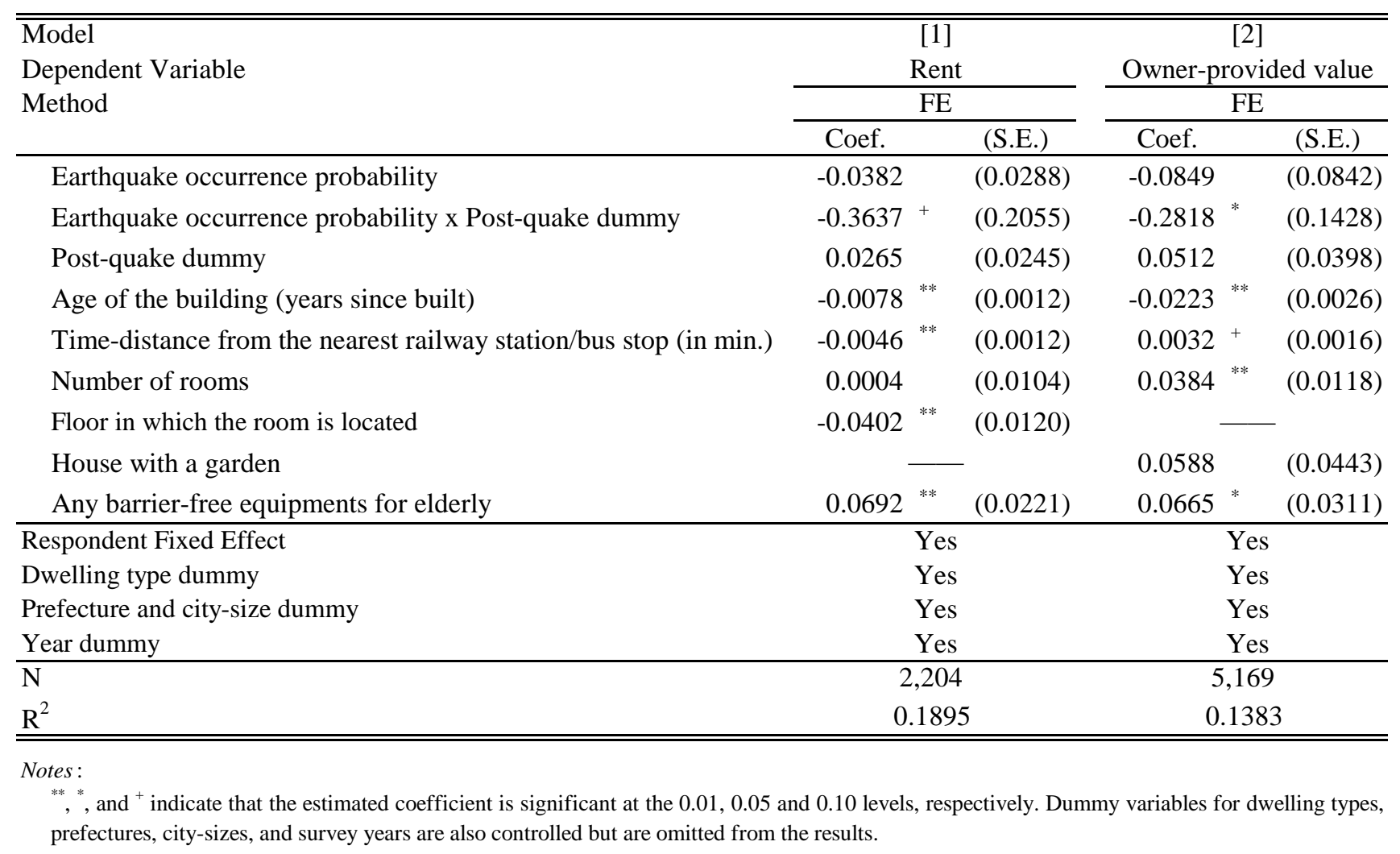


Table 4: Instrumental Variable Estimates of Hedonic Regressions

\begin{tabular}{|c|c|c|c|c|}
\hline $\begin{array}{l}\text { Model } \\
\text { Dependent Variable } \\
\text { Method }\end{array}$ & $\begin{array}{r}{[1} \\
\mathrm{Re} \\
\mathrm{FE}\end{array}$ & & $\begin{array}{r}{[2]} \\
\text { Owner-provi } \\
\text { FEI }\end{array}$ & led value \\
\hline & Coef. & (S.E.) & Coef. & (S.E.) \\
\hline Second-Stage Results & & & & \\
\hline Earthquake occurrence probability & $-0.0857^{+}$ & $(0.0466)$ & 0.1866 & $(0.2108)$ \\
\hline Earthquake occurrence probability x Post-quake dummy & $-0.4109^{+}$ & $(0.2307)$ & $-0.2526^{+}$ & $(0.1527)$ \\
\hline Post-quake dummy & 0.0293 & $(0.0253)$ & 0.0476 & $(0.0403)$ \\
\hline $\begin{array}{l}\text { First-Stage Results } \\
\text { Dependent Variable: Earthquake occurrence probability }\end{array}$ & & & & \\
\hline Within-city S.D. of earthquake probability & $-14.44911^{* *}$ & $(0.5097)$ & $-6.11144^{* *}$ & $(0.2557)$ \\
\hline Within-city S.D. of earthquake probability x Post-quake dummy & -0.1996 & (0.9739) & $-0.5203^{+}$ & $(0.3094)$ \\
\hline Dependent Variable: Earthquake occurrence probability x Post-quake & lummy & & & \\
\hline Within-city S.D. of earthquake probability & 0.0281 & $(0.0411)$ & -0.0577 & $(0.0574)$ \\
\hline Within-city S.D. of earthquake probability x Post-quake dummy & 5.5739 ** & $(0.0785)$ & $10.2008^{* *}$ & $(0.0695)$ \\
\hline Respondent Fixed Effect & $\mathrm{Y}$ & & $\mathrm{Yes}$ & \\
\hline Dwelling type dummy & $\mathrm{Y}$ & & Yes & \\
\hline Prefecture and city-size dummy & $\mathrm{Y}$ & & Yes & \\
\hline Year dummy & $\mathrm{Y}$ & & Yes & \\
\hline $\mathrm{N}$ & 2,2 & & 5,16 & \\
\hline $\mathrm{R}^{2}$ & 0.18 & & 0.135 & \\
\hline
\end{tabular}


Table 5: Robustness Check - Controlling for Neighborhood Characteristics

\begin{tabular}{|c|c|c|c|c|}
\hline \multirow{4}{*}{$\begin{array}{l}\text { Model } \\
\text { Dependent Variable } \\
\text { Method }\end{array}$} & \multicolumn{2}{|c|}{ [1] } & \multicolumn{2}{|c|}{ [2] } \\
\hline & \multicolumn{2}{|c|}{ Rent } & \multicolumn{2}{|c|}{ Owner-provided value } \\
\hline & \multicolumn{2}{|c|}{$\mathrm{FE}$} & \multicolumn{2}{|c|}{$\mathrm{FE}$} \\
\hline & Coef. & (S.E.) & Coef. & (S.E.) \\
\hline Earthquake occurrence probability & $-0.0677^{*}$ & $(0.0276)$ & -0.0740 & $(0.0836)$ \\
\hline Earthquake occurrence probability x Post-quake dummy & $-0.3556+$ & $(0.2114)$ & $-0.2807^{+}$ & $(0.1429)$ \\
\hline Post-quake dummy & 0.0262 & $(0.0253)$ & 0.0495 & $(0.0401)$ \\
\hline \multicolumn{5}{|l|}{ Neighborhood Characteristics } \\
\hline Population density (1,000person $\left./ \mathrm{km}^{2}\right)$ & $0.1034^{* *}$ & $(0.0261)$ & 0.1061 & $(0.0740)$ \\
\hline Per-capita income (1,000yen) & 0.0002 & $(0.0001)$ & 0.0003 & $(0.0003)$ \\
\hline Number of new housing starts (units/1,000person) & -0.0111 & $(0.0081)$ & $-0.0257^{*}$ & $(0.0130)$ \\
\hline Respondent Fixed Effect & \multicolumn{2}{|c|}{ Yes } & \multicolumn{2}{|c|}{ Yes } \\
\hline Dwelling type dummy & \multicolumn{2}{|c|}{ Yes } & \multicolumn{2}{|c|}{ Yes } \\
\hline City-size dummy & \multicolumn{2}{|c|}{ Yes } & \multicolumn{2}{|c|}{ Yes } \\
\hline Year dummy & \multicolumn{2}{|c|}{ Yes } & \multicolumn{2}{|c|}{ Yes } \\
\hline $\mathrm{N}$ & \multicolumn{2}{|c|}{2,204} & \multicolumn{2}{|c|}{5,169} \\
\hline $\mathrm{R}^{2}$ & \multicolumn{2}{|c|}{0.1297} & \multicolumn{2}{|c|}{0.1378} \\
\hline
\end{tabular}


Table 6: Earthquake Insurance Premium and Predicted Property Value Discounts

\begin{tabular}{|c|c|c|c|c|c|c|}
\hline & \multirow[t]{2}{*}{$\begin{array}{c}\text { Annual } \\
\text { Insurance } \\
\text { Premium } \\
\end{array}$} & \multicolumn{2}{|c|}{$\begin{array}{c}\text { Present Value of } \\
\text { Insurance Premium under } \\
\text { Different Discount Rate }\end{array}$} & \multirow[t]{2}{*}{$\begin{array}{c}\text { Annual } \\
\text { Earthquake } \\
\text { Probability } \\
\end{array}$} & \multicolumn{2}{|c|}{$\begin{array}{c}\text { Predicted Property Value } \\
\text { Discounts }\end{array}$} \\
\hline & & $3 \%$ & $5 \%$ & & Before & After \\
\hline \multicolumn{7}{|c|}{ Value of Houses $=30$ million yen } \\
\hline Rank 1 (Safest Zone) & 3.6 & 123.6 & 75.6 & $0.07 \%$ & 18.3 & 78.2 \\
\hline Rank 2 & 5.0 & 170.0 & 104.0 & $0.28 \%$ & 71.6 & 297.0 \\
\hline Rank 3 & 7.1 & 242.1 & 148.1 & $0.72 \%$ & 178.3 & 697.3 \\
\hline Rank 4 (Riskiest Zone) & 10.7 & 365.7 & 223.7 & $1.49 \%$ & 356.1 & 1261.5 \\
\hline
\end{tabular}

Notes:

Annual earthquake insurance premium is calculated based on the rate for wooden housing provided by the Non-Life Insurance Rating Organization of Japan (NLIRO). Full coverage insurance for a house with its value 30 million yen is applied. Extra discounts for earthquake-resistant buildings are ignored here. Insurance premiums and property value differentials are in 10,000 yen. 


\section{KEIO ECONOMIC SOCIETY}

\section{DISCUSSION PAPER SERIES}

No.07-1(2007) 寺出道雄「史料紹介『水野文書』」、27 pages.

No. 07-2 (2007) Mikio Ito and Shunsuke Sugiyama "Measuring the Degree of Time Varying Market Inefficiency”, 10 pages.

No. 07-3 (2007) Ayumi Onuma and Shin Sakaue "Non-cooperative and Cooperative Water Uses in a River Basin”, 20 pages.

No. 07-4 (2007) Takuji Arai and Muneki Kawaguchi “ $q$-optimal martingale measures for discrete time models", 18 pages.

No. 07-5 (2007) Takuji Arai “Optimal hedging strategies on asymmetric functions”, 9 pages.

No. 07-6 (2007) 櫻川昌哉・細野薰「日本の財政の維持可能性の

カリブレーションによる検証」、 26 pages.

No. 07-7 (2007) Koji Ishibashi "Effects of Asymmetric Information within a Firm on Oligopolistic Market Outcomes”, 23 pages.

No. 07-8 (2007) Mikio Ito “A New Method for Estimating Economic Models with General Time-varying Structures”, 18 pages.

No. 07-9 (2007) Masaya Sakuragawa and Yukie Sakuragawa

“Land Price, Collateral, and Economic Growth”, 28 pages.

No. 07-10 (2007) 河田幸視「もうひとつのサスティナブル・ツーリズム」、33 pages.

No. 07-11 (2007) Takuji Arai “Good Deal Bounds Induced by Shortfall Risk”, 22 pages.

No. 07-12(2007) Naoyuki Yoshino “Steps Toward the Development and the Integration of Asia Bond Market”, 28 pages.

No. 07-13 (2007) Naoyuki Yoshino, Sahoko Kaji and Tamon Asonuma "Dynamic Effect of Change in Exchange Rate System-Form the Fixed Exchange Rate Regime to the Basket-peg or Floating Regime”, 31 pages. 
No. 07-14 (2007) Naoyuki Yoshino, Sahoko Kaji and Tamon Asonuma "Simple rule for basket weight under basket peg regime”, 41 pages.

No. 08-1 (2008) Hideo Akabayashi and Michio Naoi "Does the Public Sector Crowd Out the Private Sector in the Higher Education Market?: Theory and Evidence from Japan”, 20 pages.

No. 08-2 (2008) 寺出道雄「比例と均衡一「経済表＼cjkstart範式」再考一」、20 pages.

No. 09-1 (2009) Michio Naoi, Miki Seko and Kazuto Sumita “Community Rating, Cross Subsidies and Underinsurance: Shy So Many Households in Japan Do Not Purchase Earthquake Insurance”, 25 pages.

No. 09-2 (2009) Michio Naoi, Miki Seko and Kazuto Sumita "Earthquake Risk and Housing Prices in Japan: Evidence Before and After Massive Earthquakes”, 30 pages. 